womanhood with little guidance, and it should inspire not merely protective or remedial measures but also courageous efforts to deal with the root causes.

\section{Chemical Industry at the Brussels Exhibition}

PUBlicity is a kind of vitamin or hormone essential for the proper growth of an industry. Like those accessories, it needs to be used constantly, judiciously and in appropriately small doses; an excess may do more harm than good, and the different varieties are more or less specific in their action. After a period of unrestrained enthusiasm, during which we sought rapidly to restore supposed deficiencies in vitamins of every alphabetical designation, we have learned to submit our requirements to the examination and prescription of experts; likewise we are learning that the best publicity is that which is well planned and well informed, that which is presented through the right channels by those best qualified, and that in which reality and literal truth are the corner-stones. The British chemical industry has been represented at many exhibitions, but for many years no demonstration of its ramifications and of the excellence of its products has been so comprehensive as that which has been arranged for the Brussels Universal and International Exhibition, 1935, opened by King Leopold on April 27. The exhibit, which is located in the British Government Pavilion, has been organised by the Association of British Chemical Manufacturers on a national basis; all sections of the industry have co-operated in its organisation and industrial firms have sunk their identity in order that the display might be truly national. It has been designed to show, by a series of tableaux, the modern applications in industry of selected chemicals. There are six main sections: heavy chemicals, agricultural chemicals, dyestuffs, coal-tar products, fine chemicals, and pharmaceutical chemicals ; there are also exhibits of rayon and of the products of the new plastics or synthetic resin industry.

Every other industry depends to-day on the chemical industry, whether in the raw material, in the means of manufacture, in testing and control, or in the finished product. New industries have been created by the application of discoveries and inventions relating to chemical substances; old industries, such as agriculture, have been given a helping hand, as in the form of fertilisers and sprays. A clear impression of the degree to which industrial chemistry and chemical industry play their part in national life and in individual well-being is offered by the booklet which the Association of British Chemical Manufacturers has prepared in connexion with the Brussels Exhibition. The English editionothers in French, German and Spanish are being prepared - is of much interest apart from the exhibits which it describes; it is a waistcoat-pocket guide to the British chemical industry rather than the programme of a show. It gives a brief account of the part which Great Britain now plays in supplying with its chemical products not only its own needs and those of the Dominions and Colonies, but also the wants of foreign countries less happily placed. The booklet contains a list of firms and organisations which have contributed to the exhibit, together with statements of their principal products. This is the right sort of publicity ; dignified, informative, accurate and interesting. The exhibitors deserve their due reward.

\section{Aborigines and Australia}

A CABLE from Adelaide in The Times of April 26 announces the composition of a Federal Board of Inquiry, which has been set up to investigate the treatment of the Australian aborigines. The Board will consist of three members, Prof. J. B. Cleland, professor of pathology in the University of Adelaide, Mr. White, acting Federal Chief Protector of Aborigines, and the Rev. J. H. Sexton, secretary of the Aborigines Friends Association of South Australia. The responsibility of the Federal Government of the Australian Commonwealth is limited to the aborigines of the Northern Territories, including the Arunta of the Alice Springs area, famous in the annals of anthropology as the tribes among whom the late Sir Baldwin Spencer and F. J. Gillen made their epoch-making investigations. Although a liberal policy has been pursued by the Federal Government in the protection of these aborigines, especially in the matter of endeavouring to ensure that they should have free access to their hunting grounds and to the springs and water-holes, allegations have been made recently that the aborigines are being forced off the land necessary to their livelihood. Attention has also been directed in a recent report of a Commission in West Australia, to which we hope to refer later, to the inadequacy of the arrangements for dealing with leprosy among aborigines. This is a Federal responsibility, a leprosarium being provided at Darwin, at which cases from the various States are received. The accommodation, it is stated, is inadequate, causing serious delay in evacuating cases from their point of origin, while, notwithstanding an agitation which has been proceeding for ten years, no steps have been taken towards a systematic examination of the aboriginal populations for the disease.

\section{Broadcasting in Great Britain}

THE Postmaster-General recently appointed a committee to consider the constitution, control and finance of the broadcasting services of Great Britain, including broadcasting to the Empire, television broadcasting and the system of wireless exchanges which will be conducted after December 31, 1936. $\mathrm{He}$ appointed as chairman Viscount Ullswater, and everyone will agree that this was a happy choice; but we were surprised to see that the committee did not include any men of science. We do not believe that any other country in the world would have appointed such a committee without a representative of science. Mr. Whitley was very proud of the new research department of the B.B.C. and was looking forward to it being a great help in the future. Already it has done valuable work, but little reference is made to it in the B.B.C. Annual for 1935. In our opinion, 
the addition of two or three scientific and technical men to this committee is necessary. So far as we can see, none of the committee has any real knowledge of the scientific principles underlying the problems its members will have to discuss. We hope that this will soon be remedied. It is necessary to consider the instructional and entertainment values of broadcasting, but it would be foolish to neglect the scientific development of the art. We have tried to find out from the Annual the amount expended in 1934 on research. Unfortunately this does not appear ; it is apparently included in the general sum of $£ 334,959$ mentioned on p. 91 for maintenance, salaries, development and research, etc.

\section{Science and Social Responsibility}

IN the April number of State Service, the journal of the Institution of Professional Civil Servants, Prof. H. Levy contributes an interesting article on this topic. The social consequences, he says, that have flowed in the wake of technical advance stand now in such clear outline that even scientific men, traditionally concerned only with the internal content of their work and not with its external repercussions, are beginning to lose their complacency. In the past, the scientific method excluded from its scope all matters involving prejudice, desire, bias or purpose, and was purely objective in character. In the logic of the physical sciences, human desires play no part, but in the social sciences they are fundamental. The pursuit of science is essentially a co-operative activity and is therefore socially conditioned. It is directed to an end, and that end is its social purpose, but since the direction which scientific investigation takes is in this way socially determined, science itself becomes one of the determining factors of society. It improves the technical level of production; it introduces new factors into the way of living for the population; it affects their cultural interests; it creates new needs and therefore arouses new hopes and desires. In almost every walk of life, laws of detailed social behaviour on which action is based are already recognised. Is it too much to suggest that here in small detail are the kinds of regularities and recurrences that make a science possible? Are we not therefore entitled to expect corresponding regularities, perhaps deeper and more far-reaching, on a large scale, and as a consequence, since society is dynamic, a logic of social change ? Since science is itself a motivating factor in that change, its study is a scientific responsibility.

\section{British Trust for Ornithology}

FIELD ornithologists in the British Isles are making an experiment in co-operative research which, if successful, may have far-reaching implications. They have a peculiar problem to deal with, partly because the great majority of them are not trained men of science, and yet are being led on to territory where an advanced scientific technique is essential. Some of the combined operations recently carried out have been on an impressive scale. The census of heronries in 1928 needed some five hundred observers before it was completed, while the great crested grebe inquiry of 1931 and the two-year woodcock inquiry now in progress have each enlisted more than a thousand observers. Naturally such work calls for a high degree of organisation, but until very recently British field ornithologists as such possessed no national organisation whatever. Irreplaceable manuscripts, field-notes, photographs, maps and collections of literature or bibliography were got together and dispersed according to the hazards of individual existence. A number of prominent ornithologists, including Mr. H. F. Witherby, president of the British Ornithologists' Union and editor of British Birds, Prof. Julian Huxley, the Rev. F. C. R. Jourdain, secretary of last year's International Ornithological Congress, and Dr. P. R. Lowe of the British Museum, combined to fill this gap by forming the British Trust for Ornithology as a permanent national trustee for the interests of field ornithologists. The Trust itself holds capital funds and assets in kind, such as a library, and collects subscriptions, which enable it to make grants for ornithological research. These grants, which at present are only on a very small scale, are being used to develop the nucleus of an Institute of Field Ornithology at Oxford, recognised and administered by the University. A national planning committee for the ornithological programme as a whole has been set up jointly by the Trust and the University.

ThE Trust's first report just issued shows that, in spite of very cramped finances, a wide range of research has already been undertaken with marked success. Special reference should be made to the enterprise of the Trust in starting an experimental annual index of heron numbers, based on a twentyfive per cent sample of the breeding heron population of England and Wales. The index for 1934 is given as 102, 1928 being taken as 100. Another interesting point is the linking up of census work on swallows with a study of the size of broods, association with domestic animals at breeding places and occurrence of certain lethal parasites. The inquiries into shorteared owl habits during a vole plague on a Forestry Commission estate, and into the effect of the recent drought on great crested grebes, are further examples of the broad range of research which this comprehensive and flexible type of organisation makes possible. The Trust is still in an experimental stage. Inquiries and offers of help should be addressed to the Honorary Secretary, Mr. E. M. Nicholson, 61 Marsham Street, London, S.W.1.

\section{Earthquakes in Persia}

Destructive earthquakes have recently visited the Persian province of Mazanderan that lies along the southern border of the Caspian Sea. The first shock occurred on April 12, and was followed by others of greater severity during the next few days. It is stated (The Times, April 24 and 27) that 28 villages have been destroyed and about 600 persons killed. The province is one that is seldom disturbed by great earthquakes, though it lies near the important centres of Teheran and Resht. Sir Arnold Wilson, in his valuable paper on earthquakes in 